システム制御情報学会論文誌，Vol. 5, No. 8, pp. 309 316, 1992

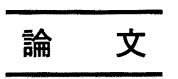

\title{
交差，合流路線上における移動ロボット群の衝突回避*
}

\author{
斉, 藤 ${ }^{* *}$. 津 村 俊 弘 ${ }^{* * *}$
}

\section{Collision Avoidance among Movile Robots Mobing on the Route Crossing and Joining*}

Mamoru Saito** and Toshihiro Tsumura***

\begin{abstract}
The problem of collision avoidance among mobile robots moving along crossing and joining paths is formulated as a motion planning problem in terms of the velocity vector modification. In this paper, a local approach based on a nonlinear programming is applied to solve this problem. Here, the velocity vector constraint for robots are set up using the relative position and velocity information of neighboring robots. The desired velocity vector, which enables robots to navigate without collision, is given as the optimal solution of objective function under this velocity vector constraint. This method is implemented using both experimental robots system and computer simulated one. From the results, it is shown that the experimental robots achieves acceptable performance both in case of crossing and joinig. The feasibility and effectiveness of our method are also discussed through the simulation results.
\end{abstract}

\section{1.はじめに}

新交通システムや工場内の無人搬送システムなどにお ける車両群の効果的な自動運行制御を行うためには, 全 車両に関する膨大な情報量, 計算量が必要とされてき た. 近年,このような移動ロボット群の制御方式として, 柔軟性, 拡張性に富んだ自律分散型制御方式が指向され つつある ${ }^{1)}$. そこでは制御入力の決定に際して, 近接す る移動ロボット間での限られた情報のみを用いるため, 個々の移動口ボットが自立性を生かしながら互いに協調 することで, システム全体としての効率化をはかること が重要な課題となってくる.

そのような協調の一つとして, ロボット間の衝突回避 問題が挙げられ, すでに幾つかの研究がなされている. Wang ${ }^{2)}$ はロボットやロボット間の相互関係, ロボット の誘導方策を, 簡単なダイナミクスで記述しロボット群 全体の力学的な挙動について考察している. 新井ら゙)は ロボットと障害物, 目標軌道との関係を, 仮想的な質

* 原稿受付 1991, 8. 3.

**大阪市立工業研究所機械課 Osaka Municipal Technical Recearch Institute, 1-6-50, Morinomiya, Jhoto-ku, Osaka 536, Japan

*** 大阪府立大学 工学部 College of Engineering, University of Osaka Prefecture, Gakuen-cho1-1, Sakai 593 , japan

Key Words : collision avoidance, mobile robot, motion planning, local approach, non-linear programming.
量・バネ・ダンパー系で記述しサーボ系を構成してロ 、ボットの誘導制御を行う方法について提案している. ま た著者ら ${ }^{4)}$ あボット間の相対的な位置, 速度情報から 幾何学的解析によって非衝突速度ベクトルを導出し, そ れぞれのロボットに対する誘導制御を行う方法について 示している.これらの方法は, いずれあロボットが自由 平面上を移動する場合の衝突回避問題を扱った研究であ る.しかしながら実際の地上交通や屋内搬送システムに おける移動体群は, あらかじめ設定された 2 次元路線 ネットワーク上で制限走行するあのが多い，このような 路線ネットワークは構造的に交差, 合流, 分岐路線から 成り, 上記の方法をそのまま適用すると, 交差, 合流路 線上でのデッドロックを生じる場合がある. その対策と しては従来からの閉塞区間制御や信号機を用いた交通管 制を適用する方法があるが，より多くの移動体の効率的 な自動運行一高密度でしかも渋滞なく一を実現する上で 十分ではない5).

そこで本論文はその基礎的な課題として, 交差, 合流 路線での移動ロボット間の局所的な協調による衝突回避 問題を取り挙げる.ここではその解法として, 非線形計 画法に基づくロボットの実時間走行アルゴリズムを適用 する. またその検証に当って試作システムによる交差, 合流路での回避走行実験ならびに計算機シミュレーショ ンによる評価を行い, 本手法の適用条件や多数のロボッ トに対する運用効果について議論する. 


\section{2. 問題設定}

交差する通路内を走行する $n$ 台の移動ロボット群を 想定する.これを図式的に示したものが Fig. 1 である. 有向直線 $l_{1}, l_{2}$ は各々の通路内におけるロボットの誘導 経路であり, 交差角 $\alpha$ をあって交差し，それぞれ他の経 路への合流路を持つあのとする.ここで各々のロボット $i$ はその作業空間の座標系 $O-x_{1} x_{2}$ における位置べクト ル $\boldsymbol{x}_{i}(t)$, 速度ベクトル $\boldsymbol{v}_{i}(t)$ を実時間で計測し, 経路に 自立誘導する手段を持つものとする．またロボットは自 己の占有領域(半径 $r$ の領域)，ならびに視覚または通 信によって他のロボットの位置, 速度情報を得るための 局所的な観測領域 (レンジ $R$, 前方視野 $180^{\circ}$ の半円領域) を持つあのとする. 本論文では走行するすべてのロボッ トを等価なものと見なし，これら二つの領域が同一であ るあのとして議論する.

\section{3. ロボットの走行アルゴリズム}

\section{1 移動拘束領域}

ここでは移動ロボット群が指示された走行ルートに 従って衝突を回避しつつ走行するための速度べクトルの 拘束領域について述べる。このような領域としては, 互 いに近接するロボット間の相対関係によって付加される 非衝突速度べクトル領域と, 個々のロボットの誘導経路 に対する追従速度べクトル領域とがある．そこでまず前 者の非衝突速度ベクトル領域について考える.いま口 ボット $i, j$ が互いにその観測領域内に侵入し, 各々の位 置, 速度べクトル情報を相互にあるサンプル周期ごとに 得るものとする. このとき, 時点 $k$ におけるロボット $j$ の ロボット $i$ に対する相対位置ベクトルを $\boldsymbol{x}_{i j}(k)\left(=\boldsymbol{x}_{j}(k)\right.$ $\left.-\boldsymbol{x}_{i}(k)\right)$, 相対速度ベクトルを $\boldsymbol{v}_{i j}(k)\left(=\boldsymbol{v}_{j}(k)-\boldsymbol{v}_{i}(k)\right)$ とすると, これらロボット間の予测最接近時間 $t_{c}$ と予测 距離関数の最小值 $L_{\mathrm{min}}$ が次式により与えられる゙ ${ }^{6)}$.

$$
\begin{aligned}
& t_{c}=-\frac{\boldsymbol{x}_{i j}(k)^{t} \boldsymbol{v}_{i j}(k)}{\left\|\boldsymbol{v}_{i j}(k)\right\|^{2}} \\
& L_{\min }=\left\|\boldsymbol{x}_{i j}(k)\right\|^{2}-\frac{\left(\boldsymbol{x}_{i j}(k)^{t} \boldsymbol{v}_{i j}(k)\right)^{2}}{\left\|\boldsymbol{v}_{i j}(k)\right\|^{2}}
\end{aligned}
$$

(1)式においてロボット $i, j$ は $t_{c}<0$ の時互いに離反 し， $t_{c} \geqq 0$ の時互いに接近することがわかる. したがっ て $t_{c} \geqq 0$ の場合に対して，これらのロボットが衝突しな い条件は

$$
L_{\min } \leqq(2 r)^{2}
$$

である．そこでこの条件を満足するロボット $i$ の修正速 度ベクトルを $\boldsymbol{v}_{i}(k)$ として (3) 式を解くと次の不等式で
現わされる $v_{i}(k)$ の非衝突領域 $h_{i j}$ が得られる7).

$$
h_{i j}=\left\{\boldsymbol{v}_{i}(k) \mid f_{i j}\left(\boldsymbol{v}_{i}(k)\right) \leqq 0\right\}
$$

ただし，

$$
\begin{aligned}
f_{i j}\left(\underline{\boldsymbol{v}}_{i}(k)\right)= & \boldsymbol{x}_{i j}(k)^{t}\left[\begin{array}{cr}
2 r & -\sqrt{\left\|\boldsymbol{x}_{i j}(k)\right\|^{2}-4 r^{2}} \\
\sqrt{\left\|\boldsymbol{x}_{i j}(k)\right\|^{2}-4 r^{2}} & 2 r
\end{array}\right] \\
& \times\left(\boldsymbol{v}_{i}(k)-\boldsymbol{v}_{j}(k)\right)
\end{aligned}
$$

この (4) 式で表現される非衝突領域 $h_{i j}$ は，幾何学的に Fig. 2 に示すようなロボット $i$ を原点とする $\boldsymbol{v}_{i}(k)$ の領 域を現わしている.この領域 $h_{i j}$ は, ロボット $\bar{i}$ の観測領 域内において接近 $\left(t_{c} \geqq 0\right)$ して来る他のロボット $j(=1$, $2, \cdots, m)$ についても同様に得られる.

次にロボット $i$ の走行経路に対する追従速度べクトル 領域としては, Fig. 3 に示すような誘導経路に平行な許 容経路幅 $2 e$ を設定する。これは次の (5)式のように表現

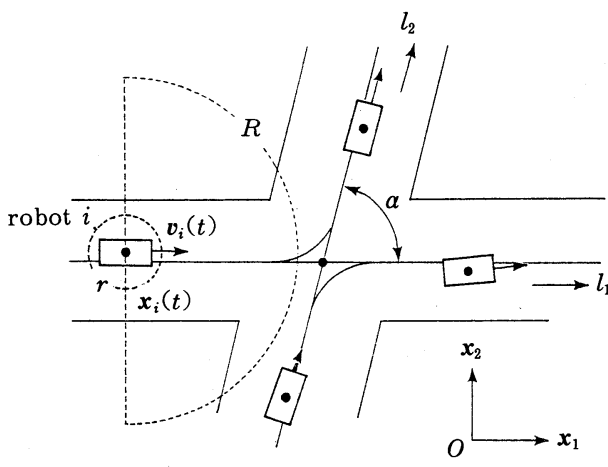

Fig. 1 Mobile robots traveling over crossing and joining paths

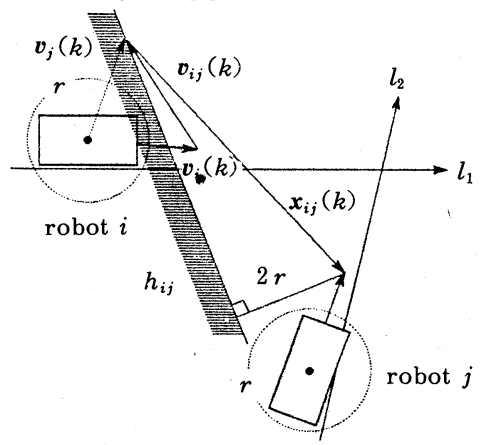

Fig. 2 Collision free velocity vector region for the $i$-th robot

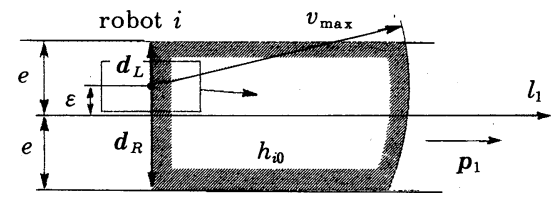

Fig. 3 Path following velocity vector region for the $\mathrm{i}$-th robot 
することができる.

$$
h_{i 0}=\left\{\underline{\boldsymbol{v}_{i}}(k) \mid \boldsymbol{f}_{i 0}\left(\underline{\boldsymbol{v}_{i}}(k)\right) \leqq 0\right\}
$$

ただし，

$$
\boldsymbol{f}_{i 0}\left(\underline{\boldsymbol{v}}_{i}(k)\right)=\left[\begin{array}{l}
d_{L}^{t}\left(\underline{\boldsymbol{v}}_{i}(k)-\boldsymbol{d}_{L}\right) \\
d_{R}^{t}\left(\underline{\boldsymbol{v}_{i}}(k)-\boldsymbol{d}_{R}\right) \\
-\boldsymbol{p}_{1}^{t} \underline{\boldsymbol{v}_{i}}(k) \\
\left\|\underline{\boldsymbol{v}_{i}}(k)\right\|-v_{\max }
\end{array}\right]
$$

ここで $d_{L}, d_{R}$ はロボット $i$ の許容経路幅に対する左右 のオフセットベクトルであり, $\boldsymbol{p}_{1}$ は走行経路に平行な単 位べクトルである，また $p_{1}^{t} \boldsymbol{v}_{\boldsymbol{i}}(\boldsymbol{k}) \geqq 0$ としているのは口 ボットを逆進させないためであり, $v_{\max }$ はロボットの最 大速度を表わしている.

以上からロボット $i$ の移動拘束領域は(4)，（5)式を満 足する $\boldsymbol{v}_{i}(k)$ の領域として次式のように記述できる.

$$
H_{i}=\left\{\underline{\boldsymbol{v}_{i}}(k) \mid \boldsymbol{F}_{i}\left(\underline{\boldsymbol{v}_{i}}(k)\right) \leqq 0\right\}
$$

ただし，

$$
\boldsymbol{F}_{i}\left(\underline{\boldsymbol{v}_{i}}(k)\right)=\left[\boldsymbol{f}_{i 0}^{t}, f_{i 1}, f_{i 2}, \cdots, f_{i m}\right]^{t}
$$

\section{2 指示速度ベクトルの導出}

先に得られた移動拘束条件下で, ロボットを走行制御 するための指示速度べクトルの導出方法について述べ る. そこでまず Fig. 4 に示される経路誘導べクトル $\boldsymbol{n}_{i}(k)$ を考える.これは経路上に設けた仮想目標点 $\boldsymbol{G}_{i}(k)$ を指向する基準速度 $v_{0}$ の速度べクトルであり， $\boldsymbol{G}_{i}(k)$ は ロボット $i$ の経路偏差 $\varepsilon\left(=\left\|\boldsymbol{d}_{L}+\boldsymbol{d}_{R}\right\| / 2\right)$ に反比例す る距離 $\xi$ に置くあのとする. すなわち誘導係数を $A=$ $\varepsilon \xi$ (const) とすると $\boldsymbol{n}_{i}(k)$ は次のようになる.

$$
\boldsymbol{n}_{i}(k)=\frac{v_{0}\left(\varepsilon\left(\boldsymbol{d}_{L}+\boldsymbol{d}_{R}\right)+2 A \boldsymbol{p}_{i}\right)}{2 \sqrt{\varepsilon^{4}+A^{2}}}
$$

さてロボット $i$ の指示速度べクトルを決定するに当たっ て, 先の (6)式の制約条件下で $\boldsymbol{v}_{i}(k)$ を最適化するための 目的関数 $J_{i}$ を以下に定義する.

$$
\begin{aligned}
& J_{i}\left(\underline{\boldsymbol{v}}_{i}(k)\right) \\
& =\bar{w}_{1}\left\|\underline{\boldsymbol{v}_{i}}(k)-\boldsymbol{n}_{i}(k)\right\|^{2}+w_{2}\left\|\underline{\boldsymbol{v}_{i}}(k)-\boldsymbol{v}_{i}(k)\right\|^{2}
\end{aligned}
$$

ただし, $w_{1}, w_{2}$ は重み係数であり

- $n_{i}(k) \in H_{i}, \quad v_{i}(k) \notin H_{i}$ の場合

$$
w_{1}=1, w_{2}=0
$$

- $n_{i}(k) \notin H_{i}, v_{i}(k) \in H_{i}$ の場合

・その他の場合

$$
w_{1}=0, w_{2}=1
$$

$w_{1}=0.5, w_{2}=0.5$

とする.ここで(8)式における第一項, 第二項はそれぞれ ロボットの経路偏差と急激な速度変化を抑制する評価項 である. ロボット $i$ の指示速度べクトルはこの $J_{i}$ を用い

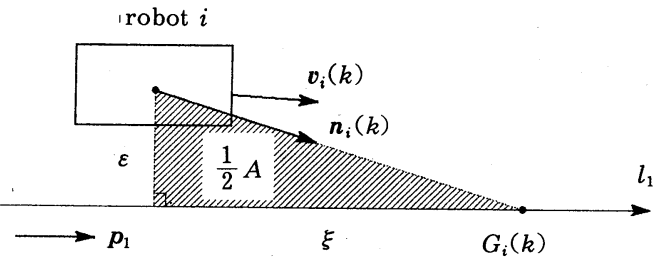

Fig. 4 Target point and path following velocity vector of the i-th robot

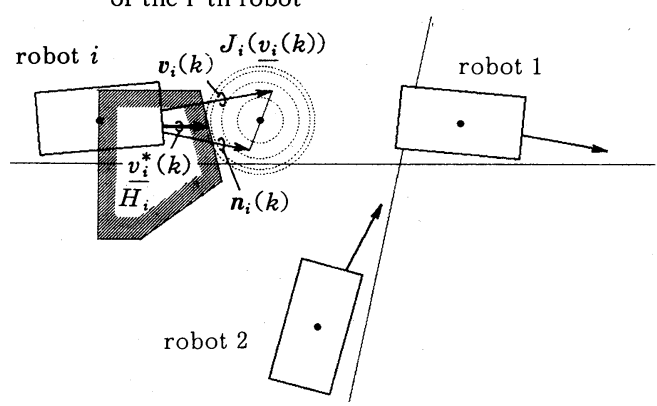

Fig. 5 Local optimization of the velocity vector

て以下の不等式制約条件付最適化問題の解として与えら れる.

minimize $J_{i}\left(\underline{\boldsymbol{v}_{i}}(k)\right)$ subject to $\boldsymbol{F}_{i}\left(\underline{\boldsymbol{v}_{i}}(k)\right) \leqq 0$

ここで $J_{i}, \boldsymbol{F}_{i}$ は $\boldsymbol{v}_{i}(k)$ に関する凸関数であり, ロボット $i$ の指示速度べクトルとして Fig. 5 に示すような (9)式の 唯一解 $\boldsymbol{v}_{i}^{*}(k)$ が得られる ${ }^{8)}$. 以上の手法をすべての口 ボットに適用し, それらの指示速度ベクトルに追従させ ることにより走行制御を行う。

\section{4. 実験}

\section{1 システムの構成}

前節の手法を検証するための基本実験に当たって，2 台の移動ロボットを用いた試作システムを製作した。 ロ ボット本体は教育用無人搬送車 $(\mathrm{PZ}-\mathrm{AC} 1$, 太平洋工業 (株)製)をべースに改造を加えたあのであり，その外観， 主要諸元をそれぞれ Fig. 6, Table 1 に示す。 ロボット のハードウェアは CPU ボード (z80A, clock $4 \mathrm{MHz})$ と 教示部(走行ルートの指定), 検出部(磁気式エンコーダ による左右 2 輪の移動量計測), 駆動部(サーボモー夕に よる左右 2 輪独立駆動)で構成し, 自立走行に必要な機 能を備えている。なお， ロボット間の相互の位置情報の 取得は24bit PIO を介した有線通信で行っている.

次にロボットの走行制御プログラムについて述べる. ここでは Fig. 7 に示すようにロボットの走行ルートの 捕捉とその速度制御を主ルーチンで行い，ロボットの位 




Fig. 6 Overview of the experimental mobile robot

Table 1 Specification of the experimental mobile robot

\begin{tabular}{|c|c|}
\hline Dimensions & $372(\mathrm{~L}) \times 250(\mathrm{~W}) \times 120(\mathrm{H})$ \\
\hline Weight & $3 \mathrm{~kg}$ \\
\hline Drive-motor & $12 \mathrm{vDC}(\mathrm{Japan}$ servo co.) \\
\hline
\end{tabular}

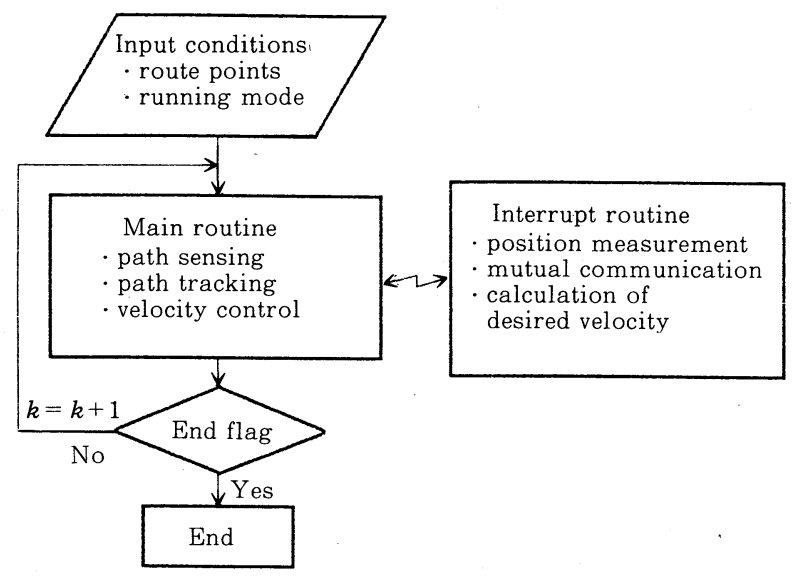

Fig. 7 Schematic flow of the running control

置計測, 通信, 指示速度ベクトルの算出を割込みルーチ ンで処理している．走行制御プログラムの開発はVAX Station 2000(DEC 社製)を用いて行っており, ロボット



\section{2 実験結果亡考察}

ここでは衝突回避の基礎実験として, Fig. 8 に示す経 路設定での交差, 合流実験を行う。なお実験においては robot 1,2 の基準速度 $v_{0}=0.20 \mathrm{~m} / \mathrm{sec}$, 最大速度 $v_{\max }=$ $0.35 \mathrm{~m} / \mathrm{sec}$, 固有領域 $r=0.238 \mathrm{~m}$, 誘導係数 $A=0.01 \mathrm{~m}^{2}$, 観測レンジ $R=0.5 \sim 2 \mathrm{~m}$ とし, 許容経路幅 $e=0.02 \sim$ $0.5 \mathrm{~m}$, 交差角 $\alpha=45^{\circ} \sim 180^{\circ}$ とした.

実験結果の一例として $e=0.2 \mathrm{~m}, \alpha=90^{\circ}, R=1 \mathrm{~m}$ とし た場合の実験状況之その時の robot 1,2 間の距離の時 間的変化について, 各々Fig. 9(a), (b) と Fig. 10 に示

†ただし $\alpha=180^{\circ}$ の場合はロボットの対面通行となり，すれ違

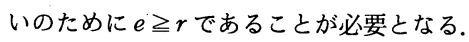

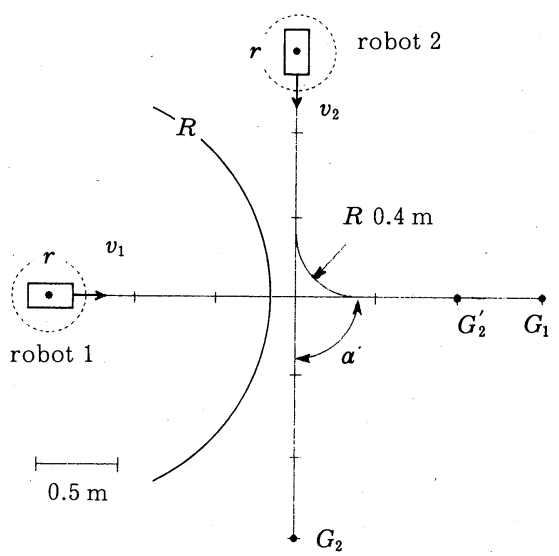

Fig. 8 Initial setup of mobile robots

す．これらより交差，合流いずれの場合あ許容 経路幅内で円滑な回避走行がなされることが確 認された．またこの場合の実験では回避に必要 なロボットの最小観測レンジ $R_{\min }$ は $0.87 \mathrm{~m}$ で あり, $R \geqq 0.87 \mathrm{~m}$ であれば $R$ の変化に対する影 響の少ないスムーズな回避動作が行われるが, $R<0.87 \mathrm{~m}$ では衝突 (robot 1,2 間の最接近距 離が $2 r$ 以下)することがわかった.

このように本手法においてはロボットのあつ $R$ は回避の成否を決定する重要な要素となる. $R$ を大きくすることは回避を容易とする反面, 観測すべきロボット数の増加を意味し，アルゴ リズムの実時間上の制約から現実性にそしい.

逆に $R$ が不十分であれば, 誘導経路の条件 $(e, \alpha)$ によっては回避が不可能となることが予想され る. そこで本手法の適用限界である $R_{\min }$ に対する $e, \alpha$ の影響について確認した.

Fig. 11 は実験における $e$ と $R_{\min }$ の関係について $\alpha$ を パラメータとしてプロットしたものである. 明らかに $e$ が大きい（経路に対する拘束が小さい）ほど回避む容易 になり， $R_{\min }$ あ小さくなることが示されている. また $\alpha$ が大きくなるに従って $R_{\min }$ あ大きくなるが，これは $\alpha$ に伴うロボット間の相対速度 $\left(\left\|\boldsymbol{v}_{12}(k)\right\|\right)$ の増加による あのである†。これらの結果より, 本手法の適用条件は, 与えられた誘導経路の $e, \alpha$ に対して $R \geqq R_{\text {min }}$ を満足す ることにある.

\section{5. 計算機シミュレーション}

\section{1 条件設定}

より多数の移動ロボットに対して本手法の適用可能性 と運用効果について検討するため, 計算機シミュレー 


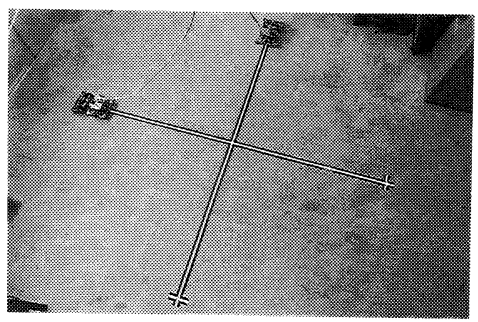

$t=0 \mathrm{sec}$



$t=9 \mathrm{sec}$

(a) crossing

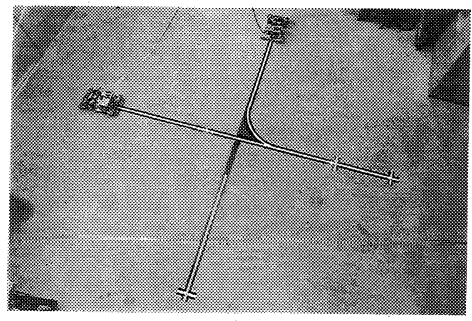

$t=0 \mathrm{sec}$

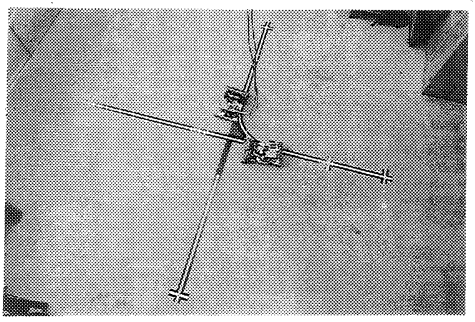

$t=9 \mathrm{sec}$

(b) joining

Fig. 9 Collision avoidance of two mobile robots

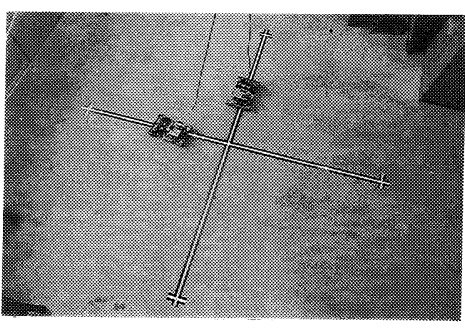

$t=6 \mathrm{sec}$



$t=15 \mathrm{sec}$

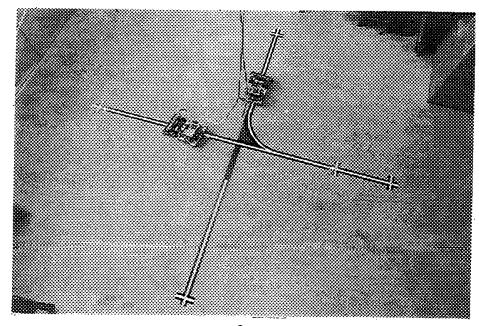

$t=6 \mathrm{sec}$

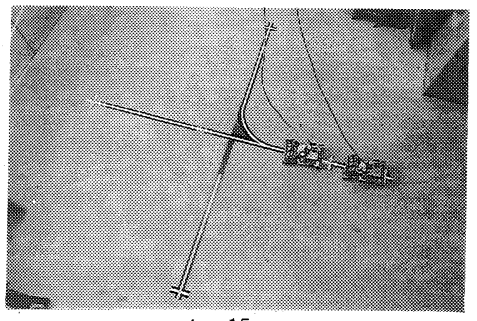

$t=15 \mathrm{sec}$

ションによる回避走行実験を行

う.ここではロボットの各種パ ラメータ $\left(v_{0}, v_{\max }, A, r\right)$ に先 の実験と同様の值を用い, 観測 レンジ $R=1.25 \mathrm{~m}$ としている. またロボットの指示速度べクト ル追従系を構成するため, その 動特性を試作システムから同定 し以下の線形方程式で近似し た.

$$
\left.\begin{array}{l}
\dot{v}+0.05 v=0.25\left(u_{R}+u_{L}\right) \\
\ddot{\phi}+0.09 \dot{\phi}=1.49\left(u_{R}-u_{L}\right)
\end{array}\right]
$$

ここで $v ， \phi は$ はそぞれロボッ 卜の進行速度, 方位角であり, $u_{L}, u_{R}$ は左右両輪の駆動入力 である.

さてシミュレーションの条件 としては Table 2 に示すよう な 6 台のロボットを用いた四つ の事例を想定する. Table 2 よ り, Ex. 1, 2 は Fig. 12(a)に示 す直角交差, 合流路における回 避実験であり, Ex. 1 は路線 $l_{1}$, $l_{2}$ の順に通行優先権を与える場 合 (robot 1, 2, 3 は robot 4, 5, 6 に対する (4) 式の拘束条件を 含めない), Ex. 2 は通行優先権 が等しい場合について検討す る. また Ex. 3， 4 は Fig. 12(b) に示す三差路での回避実験であ る.ここで Ex. 3 は路線 $l_{1}, l_{2}$, $l_{3}$ の順に通行優先権を与える場 合, EX. 4 は通行優先権が等し い場合である.

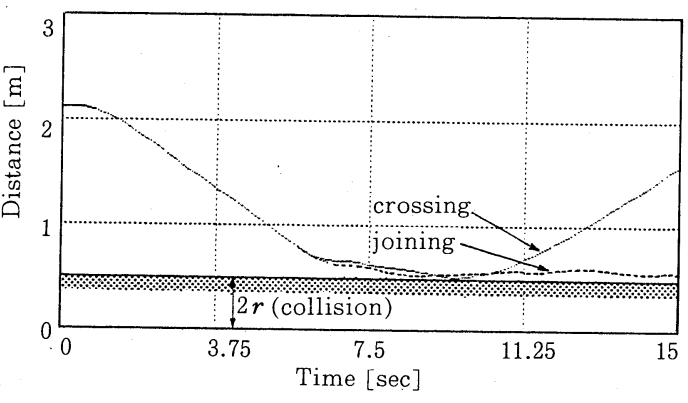

Fig. 10 Distance between crossing and joining mobile robots

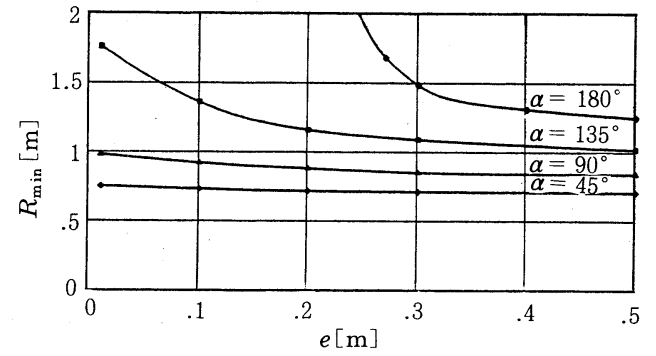

Fig. 11 Minimum range of the sensing area 


\section{2 結果と考察}

シミュレーションの結果を Fig. 13 (a)〜 (d) 亿示す.

(a)Ex. 1 では路線 $l_{1}$ 上のロボット群が通行優先権をも

Table 2 Simulation conditions

\begin{tabular}{|c|c|c|c|c|c|c|}
\hline & Ex. 1 & Ex. 2 & Ex. 3 & Ex. 4 \\
\hline \multirow{5}{*}{ path } & \multicolumn{2}{|c|}{ arrangement } & \multicolumn{2}{|c|}{ (see Fig. 9 (a)) } & \multicolumn{2}{|c|}{ (see Fig. 9 (b)) } \\
\hline & \multirow{3}{*}{$\begin{array}{c}\text { priority } \\
\text { level }\end{array}$} & $l_{1}$ & 1 & 0 & 2 & 0 \\
\hline & & $l_{2}$ & 0 & 0 & 1 & 0 \\
\hline & & $l_{3}$ & & & 0 & 0 \\
\hline & \multicolumn{2}{|c|}{ width $(e)$} & \multicolumn{2}{|c|}{0} & 0 & $2 r / \sqrt{3}$ \\
\hline \multirow{6}{*}{ route } & \multicolumn{2}{|c|}{ robot 1} & \multicolumn{2}{|c|}{$l_{1}$} & \multicolumn{2}{|c|}{$l_{1}$} \\
\hline & \multicolumn{2}{|c|}{ robot 2} & \multicolumn{2}{|c|}{$l_{1} \rightarrow l_{2}$} & \multicolumn{2}{|c|}{$l_{1} \rightarrow l_{2}$} \\
\hline & \multicolumn{2}{|c|}{ robot 3} & \multicolumn{2}{|c|}{$l_{1}$} & \multicolumn{2}{|c|}{$l_{2}$} \\
\hline & \multicolumn{2}{|c|}{ robot 4} & \multicolumn{2}{|c|}{$l_{2}$} & \multicolumn{2}{|c|}{$l_{2} \rightarrow l_{3}$} \\
\hline & \multicolumn{2}{|c|}{ robot 5} & \multicolumn{2}{|c|}{$l_{2} \rightarrow l_{1}$} & \multicolumn{2}{|c|}{$l_{3} \rightarrow l_{1}$} \\
\hline & \multicolumn{2}{|c|}{ robot 6} & \multicolumn{2}{|c|}{$l_{2}$} & \multicolumn{2}{|c|}{$l_{3}$} \\
\hline
\end{tabular}

つため, 路線 $l_{2}$ 上の $\operatorname{robot} 4,5,6$ は $\operatorname{robot} 1,2,3$ が通 過して衝突の危険がなくなるまで交差点 $O$ の手前で待 機することになる。一方，(b)Ex.2 ではすべてのロボッ 卜が(5)式の協調則に基づく回避走行を行う. 結果としてすべての回避動作が終了する 20 秒 後のロボット群の走行距離平均と標準偏差は Table 3 に示すようになり,（b)の場合のほう が全体としての運行効率がよいと判断できる. また (c)Ex. 3 と(d)Ex. 4 についても Table 3 から同様のことがいえる.ただし(d)の場合, 協調則のみに基づく回路が可能となる必要条件 は，それぞれの経路上のロボットが同時に交差 点 $O$ を通過できるだけの最小経路幅 $e_{\text {min }}$ (Fig. 14 参照)が満足されることである. このように $n$ 本 $(n \geqq 2)$ の路線が一点 $O$ で点対称に集中す るような経路設定では最小許容経路幅として

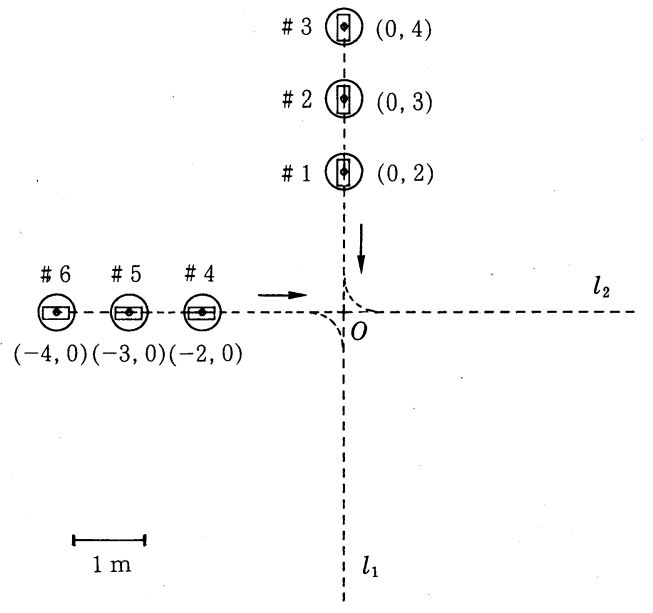

(a)

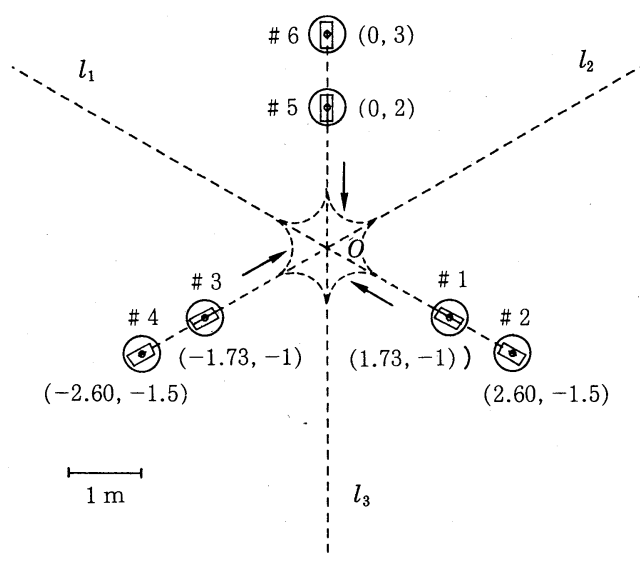

(b)

$$
e_{\min }=\frac{r}{\sin \frac{\pi}{n}}
$$

が必要となる.

\section{6. おわりに}

本論文では交差, 合流路線上での移動ロボット群の衝 突回避問題を取り上げ, 非線形計画法に基づく実時間走 行制御アルゴリズムを用いた. また試作システムによる 基礎実験と計算機シミュレーションによる検証を行い, その適用条件や運用効果について議論した. ここでは経 路ネットワークにおける基礎的課題として交差, 合流路 線に着目し, 本手法を用いることで良好な結果を得るこ とができた. 一般的な経路ネットワーク全体を想定した 本手法の応用と, ロボット群の運行効果の評価を行うこ とは，今後の課題である. なおこのような手法を実シス テムに適用することは, 従来からの一括運行制御方式と 比べて,

・上位システムの負担軽減

個々のロボットに対しては大まかな運行指示(目的地 や走行ルートなど)を与えるだけでよい.

・ システム全体の柔軟性, 信頼性の向上

運行指示の变更, 追加が容易となり, 上位システムの 故障に伴うロボットの暴走や衝突が避けられる.

などの不加価値があると考えられる.

最後に, 本研究は 1987 年度日本小型自動車振興会の補 助金の一部により行われたものである.

Fig. 12 Path arrangement for six mobile robots 

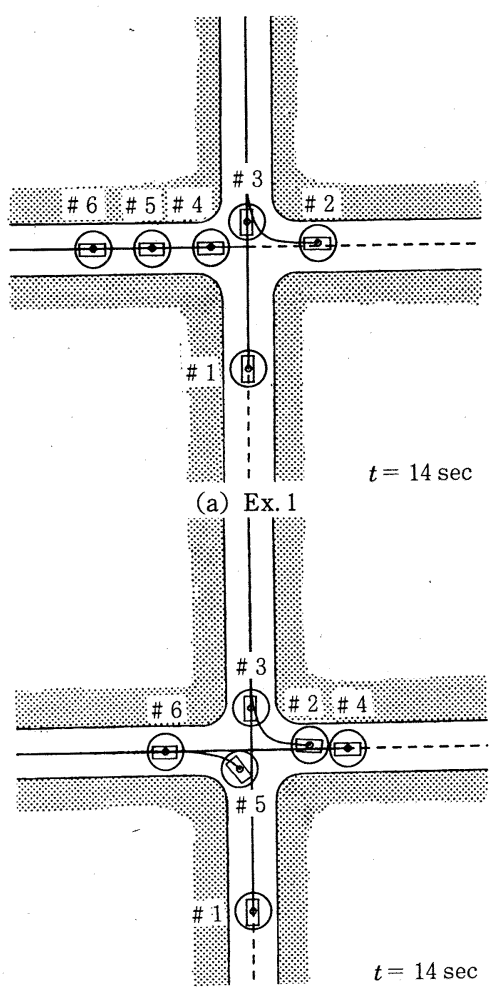

(b) Ex. 2

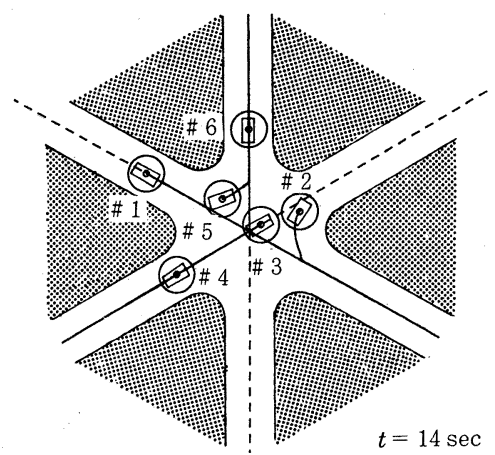

(c) Ex. 3

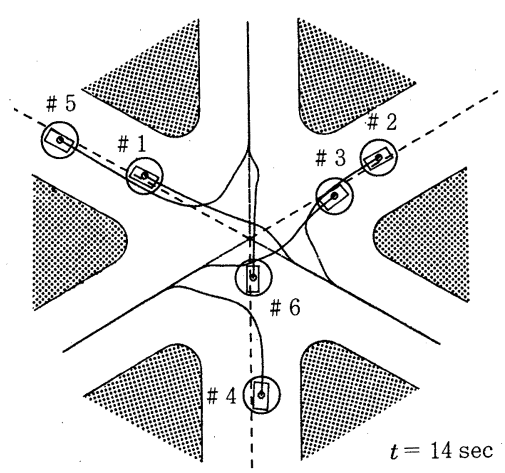

(d) Ex. 4 (Table 2)

Fig. 13 Collision avoidance of six mobile robots
Table 3 Simulation results ( $\mu$ and $\sigma$ indicate the mean and standard deviation of traveling distance)

\begin{tabular}{|c|c|c|c|c|}
\hline & Ex. 1 & Ex. 2 & Ex. 3 & Ex. 4 \\
\hline$\mu(\mathrm{m})$ & 3.40 & 4.66 & 3.45 & 4.83 \\
\hline$\sigma(\mathrm{m})$ & 1.51 & 0.48 & 0.87 & 0.24 \\
\hline
\end{tabular}

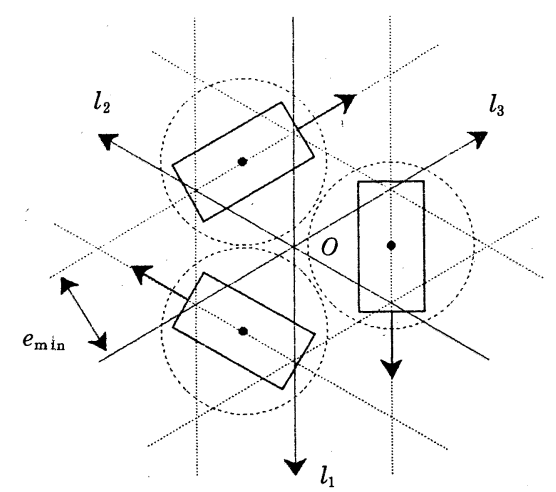

Fig. 14 Minimum path width for three symmetric paths conjunction

\section{参 考 文 献}

1）長田：自律分散システムと情報処理 ; 計測と制御, Vol. 29 No. 10, pp. 59 62 (1990)

2) P. K.C.Wang : Dynamics of Interacting Multiple Autonomous Mobile Robots with Simple Navigation Strategies; IEEE/RSJ Int. Workshop on IROS, pp. 179 185 (1987)

3) T. Arai, H. Ogata et al. : Collision Avoidance among Multiple Robots using Virtual Impedance ; IEEE/RSJ Int. Workshop on IROS, pp. 479 485 (1989)

4) M. Saito and T. Tsumura : Collision Avoidance among Multiple Autonomous Mobile Robots ; 1990 JAPANUSA Symposium on Flexible Automatiom, pp. 103 110 (1990)

5）長谷川：列車の知能化; 計測と制御, Vol. 30 , No. 1, pp. 40〜45 (1991)

6）斉藤，津村：移動ロボット間における衝突回避；システム 制御情報学会論文誌, Vol. 3, No. 1, pp. 1 7 (1990)

7）斉藤，永守：交差路線上における移動ロボット間の衝突回 避; ビークルオートメーション技術研究会第 4 回シンポ ジウム講演論文集, pp. 21 24（1991）

8）斉藤, 津村：移動ロボット群における衝突回避；システム 制御情報学会論文誌, Vol. 3, No. 8, pp. 24 32（1990） 
